\title{
Changes in numbers and distribution of breeding waterfowl in the Swedish mountain chain between 1972-1975 and 2009
}

\author{
Förändringar $i$ antal och utbredning av häckande sjöfåglar $i$ svenska fjällkedjan \\ mellan 1972-1975 och 2009
}

\author{
LEIF NILSSON \& JOHAN NILSSON
}

\begin{abstract}
During 1972-1975, the breeding waterfowl populations of the northern parts of Fennoscandia (south to $65^{\circ} \mathrm{N}$ in Sweden) were surveyed for the first time. In 2009, a new survey was undertaken in the Swedish part of the mountain chain. Censuses were performed from the air in transects of $5 \times 5 \mathrm{~km}$ squares and in special areas. The distribution of the different species was largely similar between the two periods but there were a number of differences on the regional level. Most species had more or less the same population sizes but there were some variation in the different parts of the mountains. Three species showed clear increases between the periods. Cygnus
\end{abstract}

\section{Abstract}

cygnus had the same increase in the mountain chain as in the rest of the country. Melanitta nigra was about four times as common in 2009 compared to the 1970s and Mergus merganser also had higher counts in 2009. Melanitta fusca decreased markedly in the mountain chain as along the coasts.

Leif Nilsson \& Johan Nilsson, Department of Biology, Lund University, Ecology Building, SE-223 62 Lund, Sweden.E-mail: leif.nilsson@biol.lu.se,johan.nilsson@ biol.lu.se

Received 24 Otcober 2012, Accepted 19 November 2012, Editor: S. Svensson

\section{Introduction}

The Scandinavian mountain chain like the other parts of northern Fennoscandia is rich in lakes and mires and is accordingly an important breeding area for many waterfowl species. It is also the westernmost area of several northern species which are spread from Fennoscandia in the west all over northern Russia to the east. Even if it was well known that rich waterfowl populations were breeding in northern Fennoscandia, there were no large-scale surveys until the 1970s. In 1971, the Nordic Council for Wildlife Research (NKV) organized the first survey, which was completed in 1972-1975 (Haapanen \& Nilsson 1979). During the four years systematic aerial surveys covered all of northern Fennoscandia; in Norway south to $68^{\circ} \mathrm{N}$, in Sweden to $65^{\circ} \mathrm{N}$ and in Finland to $64^{\circ} \mathrm{N}$.

Whereas staging and wintering waterfowl are regularly surveyed on an annual basis in southern Sweden (Nilsson 2008), there has been no further systematic survey of the breeding waterfowl populations in northern Sweden until 2009. In this year we got the possibility to make a new survey of the Swedish mountain chain and revisited the old survey lines and special study areas of the previous survey. In this paper we compare the census data from 2009 with the 1972-1975 data to see what changes had occurred in the distribution and numbers of the breeding waterfowl populations over the 35 year period between the two surveys.

\section{Study region}

The present study covers the Swedish part of the mountain chain and the adjoining parts of lower land to the east of the mountain chain within the province of Lapland (left of the black line in Figure 1). The former survey in 1972-1975 covered the entire area to the Baltic coast (the whole map in Figure 1) as well as extensive areas in northern Norway and Finland (Haapanen \& Nilsson 1979). During the old survey, the Lapland part of the mountain chain was split into tree sub-regions (A-C in Figure 1), which were all covered during the new survey. The total area included in the three sub-regions was $49500 \mathrm{~km}^{2}$. All areas are mainly covered by mountains.

Sub-region A (northern sub-region) has some high mountain areas, but a larger part, especially in the north consists of low-lying fells and plateaus at a level of about $400-600 \mathrm{~m}$ a.s.l. There is only little coniferous forest in the most low-lying parts. 


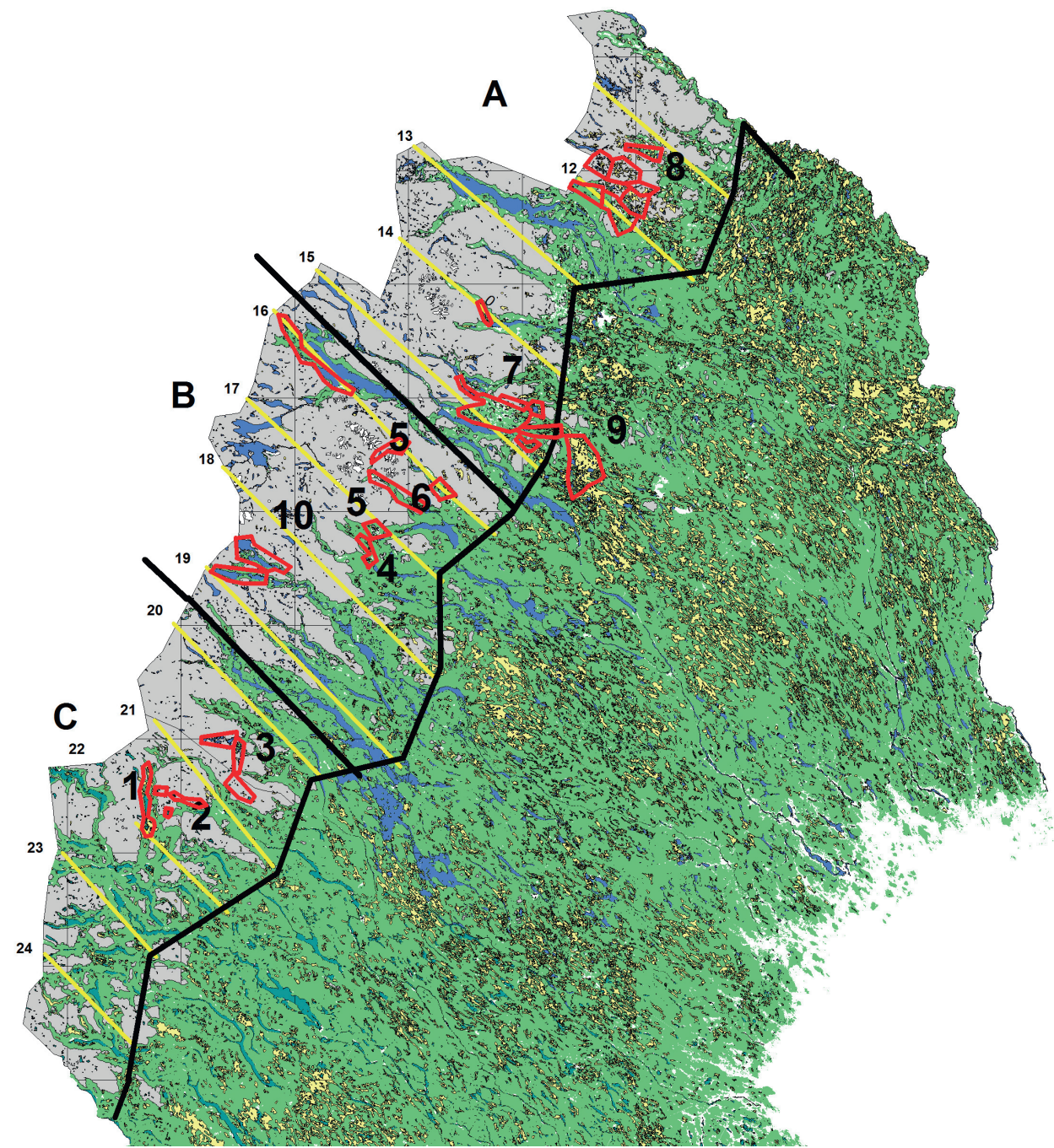

Figure 1. Map of northernmost Sweden showing the area surveyed in 2009, covering the Lapland part of the mountain chain and neighboring areas. The map also shows the division into sub-regions used in the 1972-1975 survey (Haapanen \& Nilsson 1979), survey lines (yellow) and the special study areas (red, numbers in black). Alpine areas (above tree line) are shown in grey. Karta over norra Sverige med det inventerade området $i$ lapplandsdelen av fjällen och fjällnära områden markerat. Kartan visar också regionindelningen från inventeringarna 1972-1975, inventeringslinjerna (gult) samt specialområdena (rött, nummer $i$ svart). Kalfjällområdena markeras med grå färg. (C) Lantmäteriet Medgivande i2012/0911.

Subalpine birch woods and alpine vegetation are the predominant vegetation types. About $9 \%$ of this sub-region is covered by water and the lakes are mostly rather small. Most mires in the mountain area are of the palsa peatland type, but there are some of the aapa fen type at the border to the forest regions, especially in the Sjaunja nature reserve (special area 7).

Sub-region B (middle sub-region) is a high mountain area, including the highest mountains in
Sweden with lakes up to 1200 m.a.s.l. Lakes cover $11 \%$ of this sub-region and there are 16 larger lakes with an area of more than $100 \mathrm{~km}^{2}$. About one third of the sub-region is forest with a zonation from birch to conifers in the deep valleys and along the eastern border.

Sub-region C (southern sub-region), which is the southernmost sub-region has lower mountains with wetlands mostly at an altitude of 600-800 m.a.s.l. Water covers $6 \%$ of the area. As in the other parts 
of the mountain chain most lakes are typically oligotrophic but there are some richer lakes in areas with more basic bedrocks. Although alpine habitats predominate, forest cover is approaching half of the sub-region with considerable elements of conifers in the lower and eastern parts.

For a more detailed description of the different sub-regions with statistics of the coverage of different vegetation types, mires and lakes etc. see Haapanen \& Nilsson (1979). Typical wetland habitats are illustrated with photos in Figure 2.

\section{Material and methods}

To be able to calculate total populations for the different species and to be able to compare the species distributions with habitat factors, a system of transects were laid out over the entire northern Fennoscandia, using the UTM-system. Following the north-west to south-east diagonals of the $100 \times 100$ $\mathrm{km}$ squares of this reference system, squares $5 \times 5$ $\mathrm{km}$ in size and connected to each other in their corners, were used. In the old survey, the transects extended from the Norwegian border to the Baltic coast, giving a $5 \%$ coverage of the entire area. To obtain a better coverage in the mountain chain with its much more variable habitats, and in the mire areas just to the east of the mountain chain, additional transects were laid out between the main transects, thus yielding a coverage of $10 \%$, The geographical positions of the transects used in the current study can be seen in Figure 1.

In addition to the transects, a system of special study areas was set up in important waterfowl habitats to study annual variation of waterfowl populations. These areas covered different habitat types and were surveyed each of the four initial years 1972-1975 and 2009. The geographical positions of the special study areas can be found in Figure 1. All in all, 34 such areas were established but in this study they have been grouped into 10 larger areas, of which 8 (numbers 1-8 in Figure 1) are included in the analysis of population changes. The different special study areas are exemplified with photos and short descriptions in Figure 2.

During the surveys all water areas and other wetlands within each transect square were covered from an aircraft allowing all suitable waterfowl habitats in the areas to be surveyed efficiently. In 1972-1975 a fixed-winged CESSNA 172 and 185 were used for the surveys, whereas a small helicopter was used in 2009. The total flying time for the 2009 survey was 45 hours (for details for 1972-75, se Haapanen \& Nilsson 1979). During the surveys, we were flying at a low altitude $(50-70 \mathrm{~m})$ with a low speed over the water areas and wetlands. If birds could not be directly identified and counted, the area was circled until a good count and identification could be obtained. Two experienced observers performed the aerial survey and the front observer besides the pilot kept track of the navigation within the squares. During the 2009 survey we had the advantage of using a GPS to document the track of flights whereas this technology was not available in the earlier surveys.

All observations were registered on a dictaphone with information of species, number of pairs, number of males and females in each group and any special observations. The observations were later transferred to a database. We considered counts of pairs and males in groups of 1-3 males as an indication for the number of pairs of each species in the squares/areas. Pure male groups with more than 3 birds were not included in the pair estimates.

In all, 210 squares were situated in the region that was covered in this study. During the surveys in 1973-1975 all wetlands in 38 high-altitude squares were completely covered in ice at the time of the survey and an additional 9 squares did not have any water areas (high mountains). During 2009 we surveyed 114 squares; 65 high altitude squares were not covered due to lack of water areas or due to being totally frozen, and 31 squares were not covered due to other reasons (military flight restrictions etc.).

The special study areas were surveyed in a manner similar to that used for the transect squares. These areas were selected to represent different important waterfowl habitats and different parts of Lapland. The areas 1-8 (Figure 1) were surveyed in each of the four years 1972-1975 and in 2009, whereas areas 9 and 10 were counted in 2009 and at some other occasions.

Even with the method used here, where all potential waterfowl areas within the surveyed squares and special study areas were covered as closely as possible, there are marked differences in the detectability of the different species from the air. During the 1972-1975 survey (Haapanen \& Nilsson 1979), extensive comparisons of efficiency between ground and aerial counts, different aerial crews and fixed-winged airplanes and helicopters, were conducted. These comparisons produced species-specific correction factors for estimating total populations. Similar efficiency studies have been made by Nilsson (1975) and Martinson \& Kaczynski (1967). However, the results from these comparisons showed that there is little difference of 


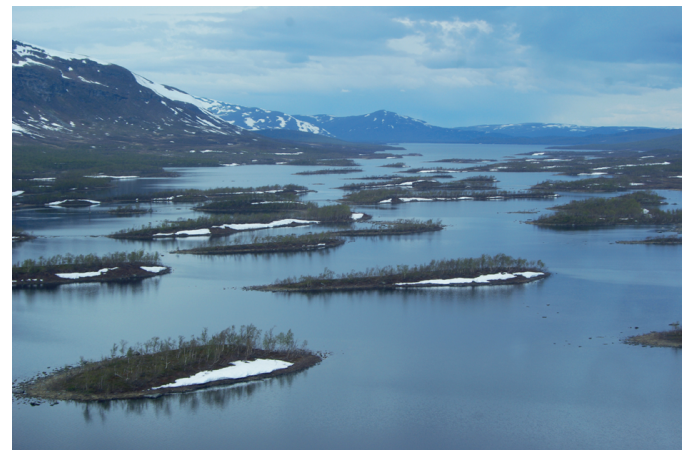

1 Tärnasjön

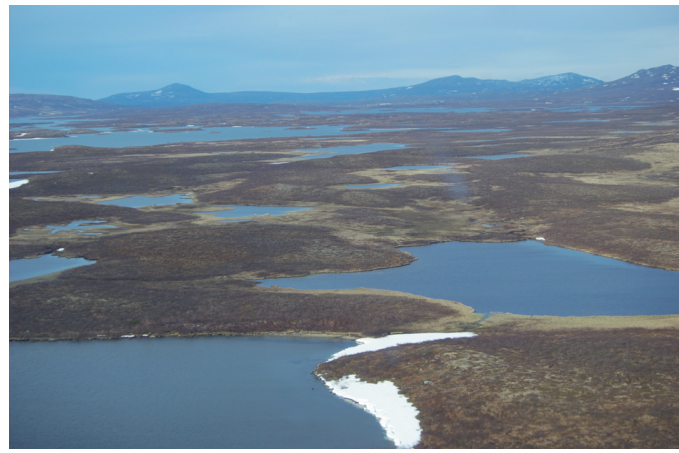

3 Tjålmejaure - Björkfjället

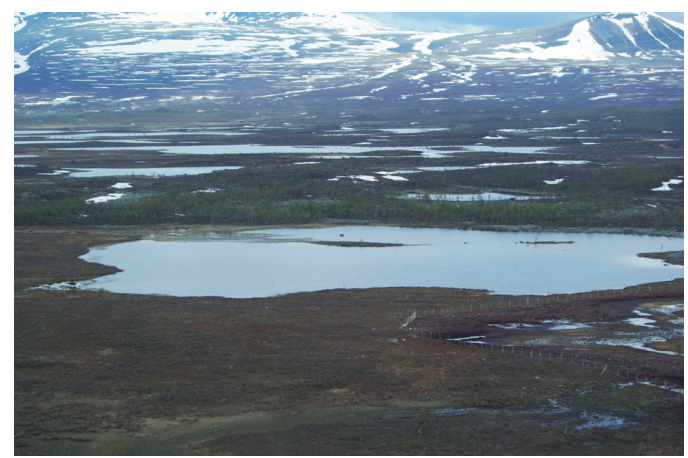

5 Pårek och Kukkesvagge

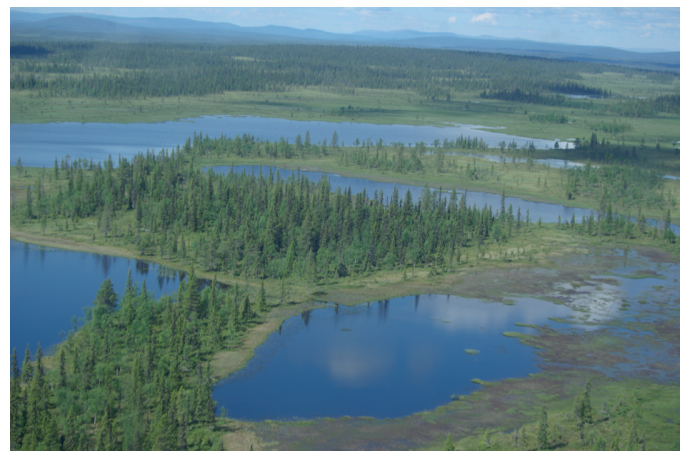

7 Sjaunja - Kaitum

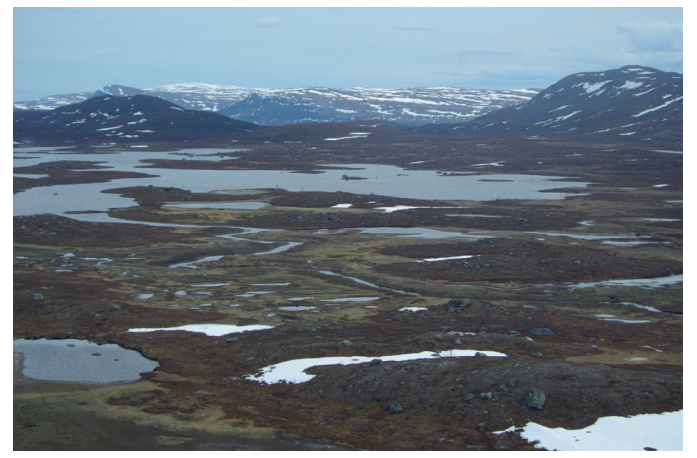

2 Södra Ammarfjället

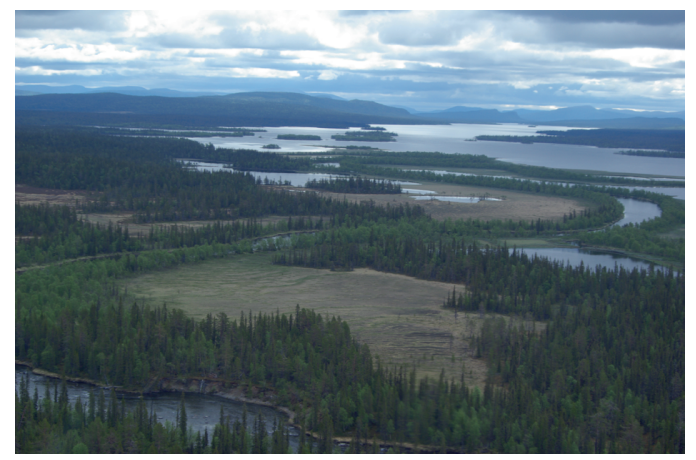

4 Kvickjokk

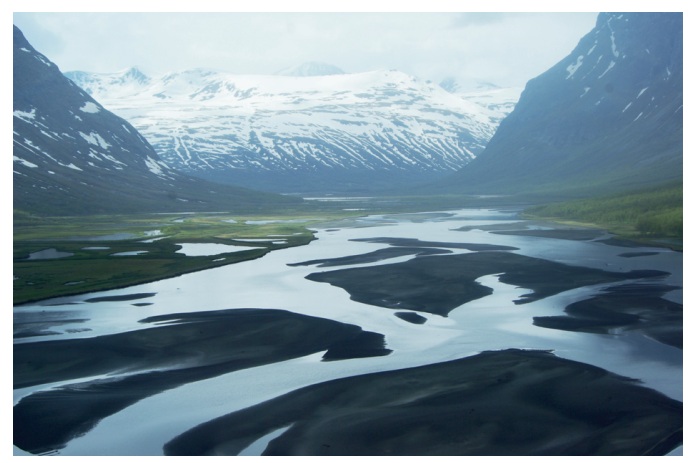

6 Rapadalen

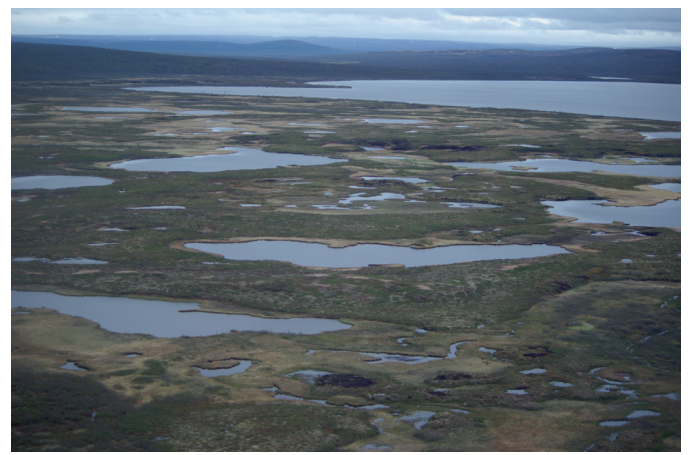

8 Tavvavuoma -Tsåktso -Pirtimäsvuoma 


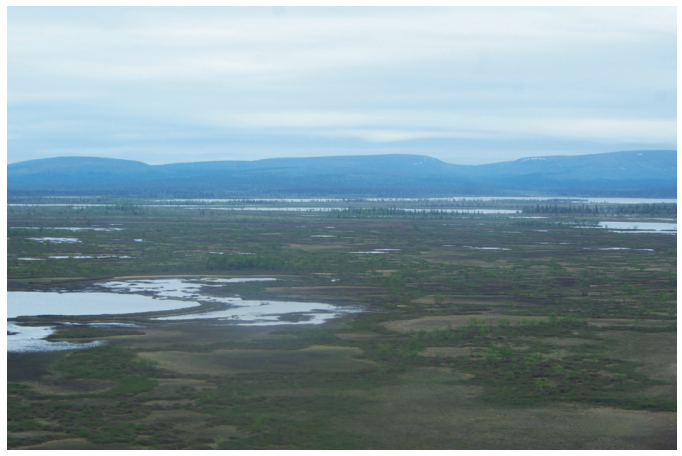

9 Muddus

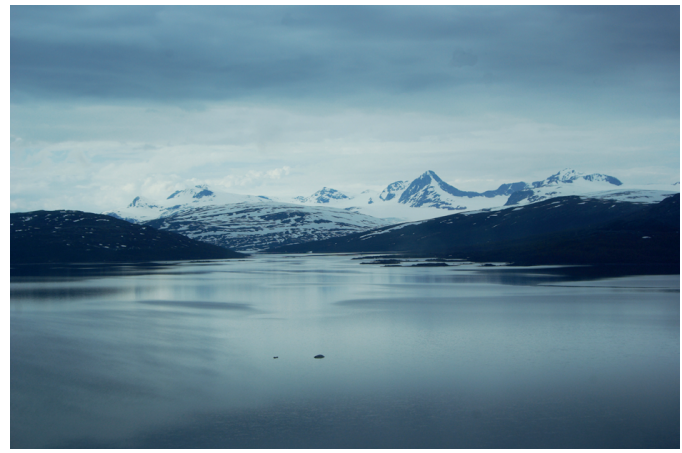

10 Peskehaure

Figure 2. Examples of different waterfowl habitats within the special study areas in the Lapland part of the Swedish mountain chain. For geographical position of the special study areas see Figure 1.

Exempel på olika andfågelhabitat inom specialområden i den lappländska delen av svenska fjällkedjan. De olika specialområdenas läge framgår av kartan i Figur 1.

1. Tärnasjön is a large lake in the birch forest zone with an archipelago, surrounded by large mire areas with numerous lakes of different sizes.

Tärnasjön är en stor sjö i fjällbjörksregionen med en omfattande skärgård, omgiven av stora myrområden med talrika sjöar av olika storlek.

2. S. Ammarfjället is an alpine plateau with numerous lakes of various sizes in the low alpine zone.

S. Ammarfjället är en alpin platå med talrika sjöar av olika storlek $i$ den lågalpina zonen.

3. Tjålmejaure-Björkfjället is a plateau in the low alpine zone with a large number of small lakes and some larger shallow lakes. Tjålmejaure - Björkfjället är en platå i den lågalpina zonen med talrika småsjöar och några store, grunda sjöar.

4. Kvickjokk is a delta area in the coniferous zone fed by rivers from the high alpine areas of the Sarek national park. It has many rich small ponds and lakes.

Kvickjokk är ett deltaområde $i$ den övre barrskogsregionen format av älvar från den högalpina regionen i Sareks nationalpark. Det har många rika dammar och sjöar.

5. Pårek and Kukkesvagge are two areas in the border zone of the high alpine areas of Sarek and a valley in the Sarek mountains, respectively. Pårek is in the low alpine zone, Kukkesvagge in the middle alpine zone. Both areas are characterized by a large number of small lakes in a rather barren area.

Pårek och Kukkesvagge består av två områden i gränszonen till de högalpina områdena i Sarekfjällen respektive en dalgång $i$ Sarek. Pårek är beläget $i$ den lågalpina zonen, medan Kukkesvagge ligger i den mellanalpina zonen. Båda kännetecknas av ett stort antal småsjöar i fattig terräng.

6. Rapadalen is a large mountain valley coming from the high alpine areas of Sarek national park. The valley opens up in a large delta with many pools and small lakes and with rich sediments from the glaciers in the high mountains.

Rapadalen är en stor dalgång som kommer från de högalpina delarna av Sareks nationalpark. Dalen öppnar sig i ett omfattande delta med många dammar och småsjöar och med rika sediment från glaciärerna i de höga fjällen.

7. Sjaunja - Kaitum consists of the large Sjaunja nature reserve extending for a vast area to the east of the mountain chain including large numbers of small rich lakes and large mires of the aapa type. It extends from the lower birch forest zone close to the mountains to the coniferous zone.

Sjaunja - Kaitum omfattar det stora Sjaunja naturreservat öster om fjällkedjan och innefattar ett vidsträckt område med talrika småsjöar och stora myrar av aapa-typ. Området sträcker sig från björkskogsregionen nära fjällen till barrskogsregionen.

8. Tavvavuoma - Tsåktso-Pirtimäsvuoma are large tundra-like areas in the northernmost part of the Swedish mountain chain characterized by large areas of palsa peatland with numerous small ponds and shallow lakes.

Tavvavuoma -Tsåktso -Pirtimäsvuoma är stora tundralika områden i den nordligaste delen av den svenska fjällkedjan kännetecknade av stora palsmyrar med talrika dammar och småsjöar.

9. Muddus is a national park in the coniferous zone with large mires of aapa type and numerous small lakes and ponds.

Muddus är en nationalpark $i$ barrskogsregionen med stora myrar av aapa-typ och talrika småsjöar och dammar.

10. Peskehaure and neighboring lakes are open large oligotrophic lakes close to high mountains and the area only includes smaller areas with shallow water.

Peskehaure med angränsande sjöar är stora oligotrofa sjöar nära de höga fjällen och omfattar endast mindre områden med grunt vatten. 
survey efficiency between fixed-winged airplanes and helicopters.

The timing of the surveys is crucial for the results especially in the mountain chain, where there are large altitudinal differences between areas and accordingly also large differences in the timing of ice melting. Ducks normally stay in pairs only for a short period after arrival to the breeding grounds. Shortly after their arrival the pairs spread out and the males leave the incubating females to tend for themselves.

In the 1972-1975, surveys were undertaken over a longer time-span, allowing different altitudinal areas to be visited at the optimal survey time. In 2009 this was not possible (all surveys were undertaken during the period 9-16 June) and some areas were therefore surveyed somewhat too early for the higher altitudes to be adequately covered. This mainly affected sub-region B, where many of the higher lakes were covered by ice at the time of the survey. As the aim of the 2009 survey was to compare the counts with those of the earlier survey for the whole mountain region, the timing is not crucial as the ducks going for higher altitudes are found during the surveys of more low-lying areas with open lakes, but timing will of course affect the detailed distribution of the waterfowl. Suitable staging areas east of the mountains for the birds aiming to higher areas were well covered in the surveys.

\section{Results and discussion}

The distribution patterns of the more common and wide-spread species in 2009 are compared with those of 1973-1975 in Figure 3. Number of pairs and squares with observation is given in Table 1. For distribution maps for the entire northern Sweden in 1972-1975, see Haapanen \& Nilsson (1979). Numerical data on each species and each special study area are given in Table 2, whereas Figure 4 presents totals for the special study areas covered all years. The results are described in more detail and discussed below for each species.

The surveys of the special study areas during the first survey period, 1972-1975, revealed marked fluctuations in number of pairs between the different years (Figure 4) for some species, whereas other species showed more consistent numbers. The data from the special areas permit a more detailed analysis of the changes (ANOVA, correlated samples). Generally, this analysis also indicates that the number of changes are comparatively few or hidden in two much noise. Nine species give proba- bilities that are far from significant $\left(\mathrm{F}_{4,7}<1.9\right)$. Only two changes are significant between the old and new surveys. It is the increases of the Black Scoter $\left(\mathrm{F}_{4.7}=3.3 ; \mathrm{p}<0.01\right)$ and the Goosander $\left(\mathrm{F}_{4,7}=7.4\right.$; $\mathrm{p}<0.001)$. In both species there is no significant difference between the years of the 1970s but all these four years differ significantly from 2009 (Tukey HSD tests). In two species, Goldeneye (increase) and Velvet Scoter (decline) the test probability is approaching significance.

The more common species will be commented on below, whereas we refer to the Tables for the less common species.

\section{Wigeon Anas penelope}

The Wigeon is the only species of dabbling ducks seen in a sufficient number of squares for meaningful comparisons between the two time periods. In 2009 the southern subregion showed the highest representation of Wigeons whereas they were most common in the northern sub-region in 1973-1975. There were marked differences between different special study areas. Numbers counted in the south were relatively low, but the counts in 2009 were higher than in the 1970s. For the two major delta areas studied, Kvickjokk and Rapadalen (Table 2), marked differences were found. At Kvickjokk the count was higher in 2009 compared to the 1970s, whereas the count at Rapadalen had changed in the opposite direction. In Sjaunja-Kaitum and in the Tsåktso-Tavvavuoma areas the number of Wigeons was markedly lower in 2009 compared to the 1970s.

\section{Scaup Aythya marila}

For the Scaup the southern part dominated the distribution in the transects, especially during the first survey, whereas some more Scaups were found in the north during the second survey. The combined counts in the special study areas and transects show similar population levels in the two periods. Marked differences were however found between the different special study areas. In the southern areas (1-3), the Scaup was less common in 2009 in Tärnasjön (1), whereas numbers were higher in S Ammarfjället (2). Tjålmejaure (3) had relatively similar numbers in both time periods. Numbers were relatively high in Rapadalen (6) in 2009 compared to the earlier surveys, whereas Scaups were less common in 2009 both in the Sjaunja-Kaitum (7) and the Tsåktso-Tavvavuoma (8) areas, i.e. there seems to be a decline in the northern areas, whereas the species was on the same level in the south. 
Tufted Duck Aythya fuligula

The Tufted Duck had a new distribution pattern in 2009. There was a distribution gap in sub-region B in the 1973-1975 survey, whereas no such gap was found in the 2009 survey. The Tufted Duck was found in the lakes up to the highest altitudes of ice-free areas. Since the total numbers counted did not differ much, the change must partly be a re-distribution.

Tufted Duck counts, especially in some special study areas indicate an increase between the two time periods. The mean total for special areas $1-6$ increased markedly between the two periods from 27 to 224 , whereas on the other hand the combined mean for areas 7 and 8 decresed from 193 to 120 pairs. A very high count in Rapadalen (6) in 2009 was probably related to the ice-coverage in higher altitudes this year; see also the relatively high count here for the Scaup in 2009. This aggregation of Tufted Duck pairs in a "waiting area" close to the high mountain area could influence the overall estimate for the species. Due to the possible effect of Tufted Ducks waiting for the ice to break up in some special areas it is uncertain whether the increase noted is in line with the increase that has been found in the winter indices for the species (Nilsson 2008) or merely due to local effects.

\section{Goldeneye Bucephala clangula}

The Goldeneye is mainly a species of the forest zone and is well spread over most parts of northernmost Sweden. It was well represented in the valleys and birch forests of the mountain chain in both surveys and no marked changes in distribution or numbers were found.

\section{Long-tailed Duck Clangula hyemalis}

The Long-tailed Duck is a species confined to the alpine zone and especially to areas with small lakes and ponds such as the palsa peatlands in the northernmost part of the mountain chain. In the southern sub-region, only one occurrence was recorded in both surveys. But in the middle subregion, not a single count was made in 2009, compared to a dozen of occurrences in 1972-1975. This absence from the transects in the middle subregion was most probably an effect of the timing of the surveys. In 2009 we had the possibility to survey the higher elevations during only a single day when the breeding lakes were still to a large extent frozen. In 2009 we found a concentration of no less than 29 pairs of Long-tailed Duck in a large lake (Peskehaure) in special study area 10 within the middle sub-region, where they appar- ently waited for the breeding lakes to be free of ice.

In the Long-tailed Duck, the transects showed a lower total for 2009 than in the early period. This was most likely caused by ice-coverage in, especially, the southern and middle subregion. The comparisons of surveys in the special study areas also showed somewhat lower numbers in 2009 compared to the 1970 s, but not markedly so. Some of the lakes mentioned above, where Long-tailed Ducks aiming for the higher lakes gathered waiting for the ice to break, were included in the special study areas.

The higher lakes at Pårek-Kukkesvagge (5) on the border to the high-alpine areas of Sarek were mostly ice-free but still had no Long-tailed Ducks. The number of the Long-tailed Ducks in the palsa peatlands at Tsåktso-Tavavvuoma (8), which form one of the major habitats for the species in the Swedish mountain chain, was lower in 2009 compared to three of the four study years in the 1970s.

\section{Velvet Scoter Melanitta fusca}

The Velvet Scoter, had undergone a drastic change, from having been spread over almost the whole study region in 1972-1975 to being recorded at only a few sites in the southern and middle subregions in 2009.

For the transects the number of pairs counted decreased from 56 to 19 , whereas the decrease for the special study areas was from 85-95 pairs to about 60 pairs. This decrease was found in all areas except Tjålmejaure-Björkfjället (3), where the population level was the same in the two periods. In the Tsåktso-Tavvavuoma (8) area, not a single pair was found in 2009 compared to $19-30$ in the earlier census.

This species has its main inland distribution in the mountain chain, with only scattered pairs found in the forest regions in the 1970s (Haapanen \& Nilsson 1979). As for the Common Scoter we have no new data elucidating the situation in the forest zone. The Velvet Scoter is also a breeding bird in the archipelagos of the Baltic coast. The overall trend for the species in Sweden is a very marked decrease over the last 30 years (Ottvall et.al. 2009).

\section{Common Scoter Melanitta nigra}

The Common Scoter was similarly distributed over the entire study region during both surveys but occurred in many more squares in 2009 than in 1973-1975. Numerically it was about five times more common in the latter period compared to the 

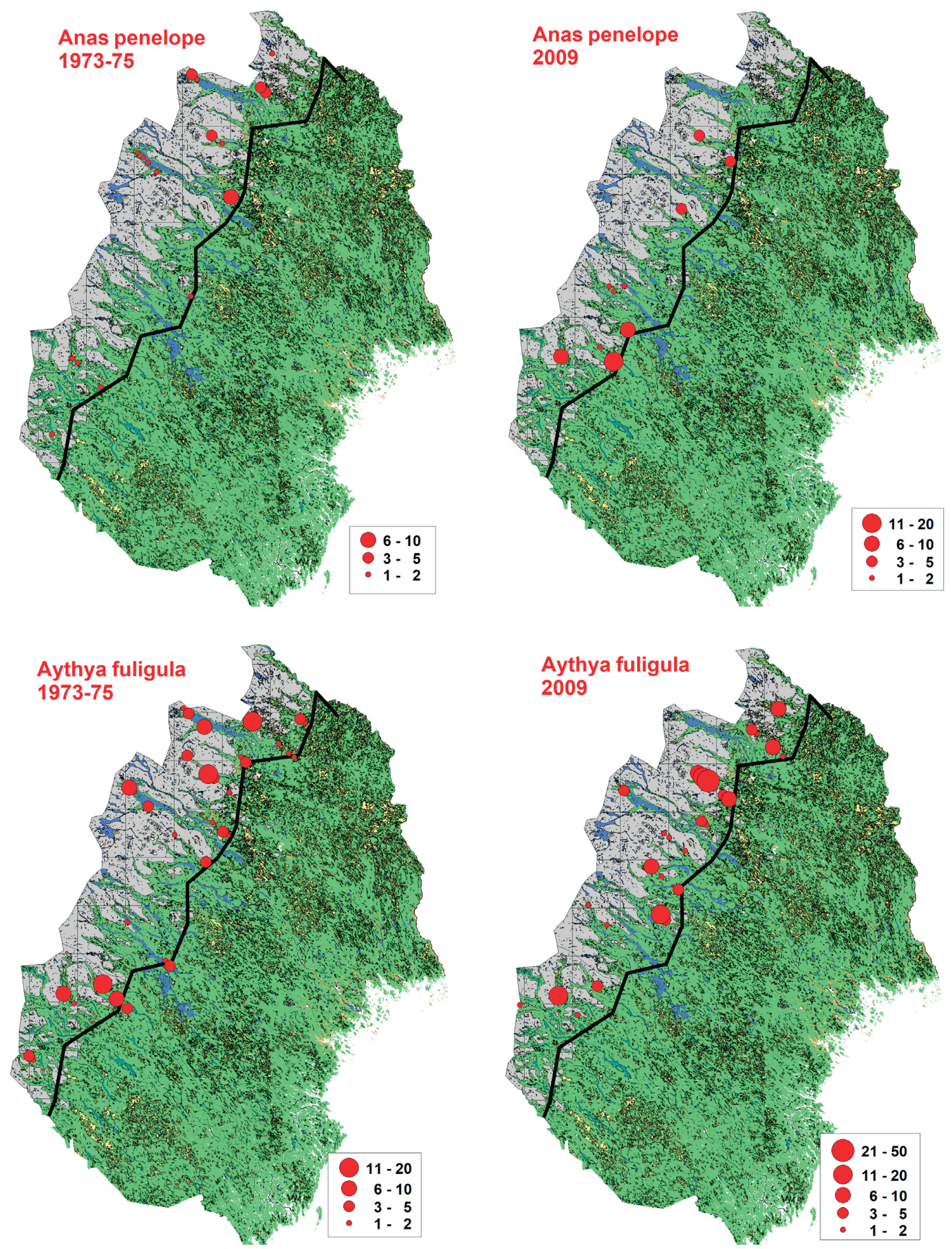

Figure 3. The distribution of different waterfowl species at the surveys 1972-1975 and 2009. The number of pairs in each square is shown by the size of the symbols. The area west of the black line was surveyed. 

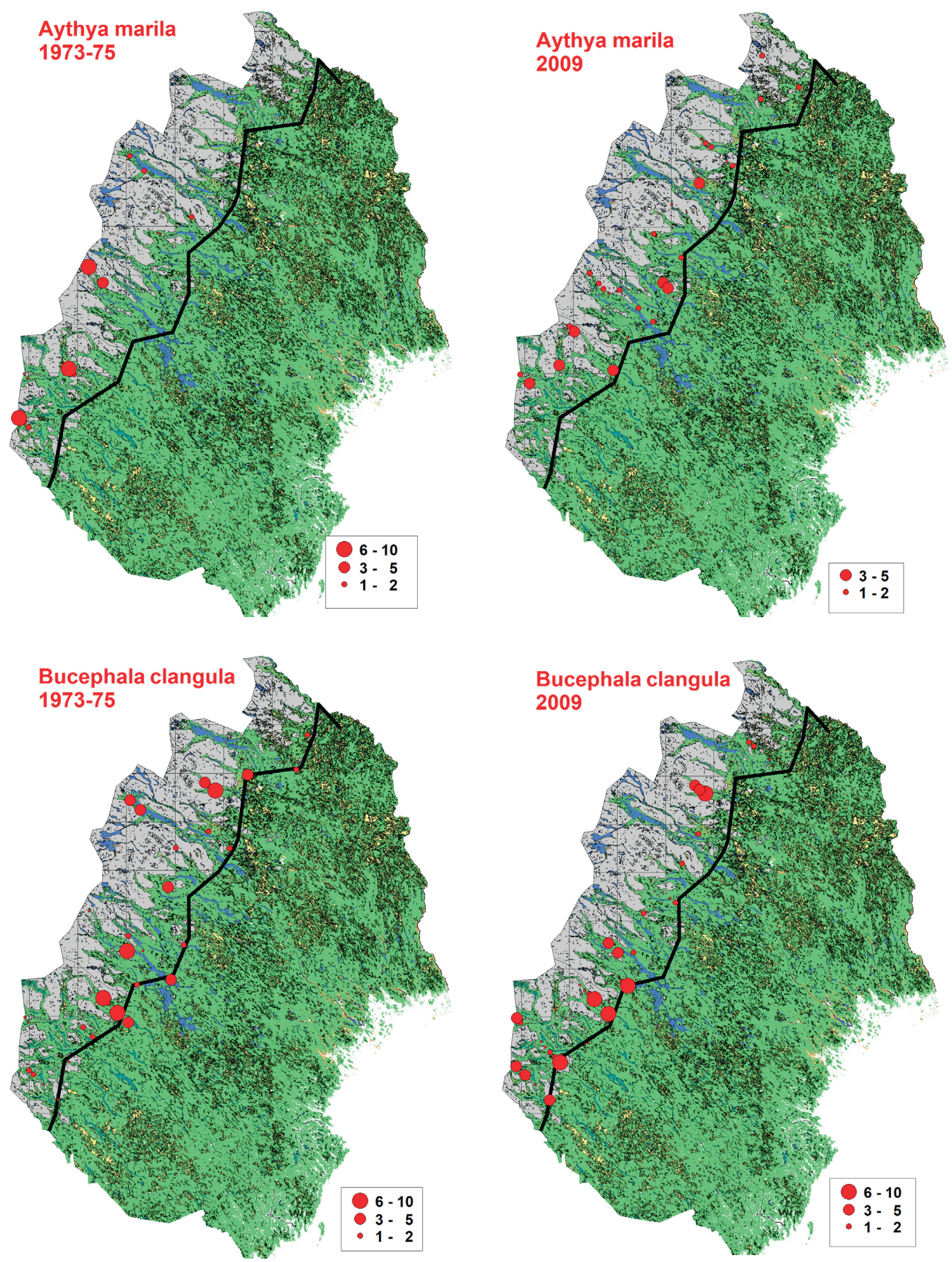

Utbredningen för olika andfägelarter vid inventeringarna 1972-1975 och 2009. Antalet par i varje ruta anges med olika storlek på symbolerna. Gränsen (mot öster) för det inventerade området visas med en svart linje.

(c) Lantmäteriet Medgivande i2012/0911. 

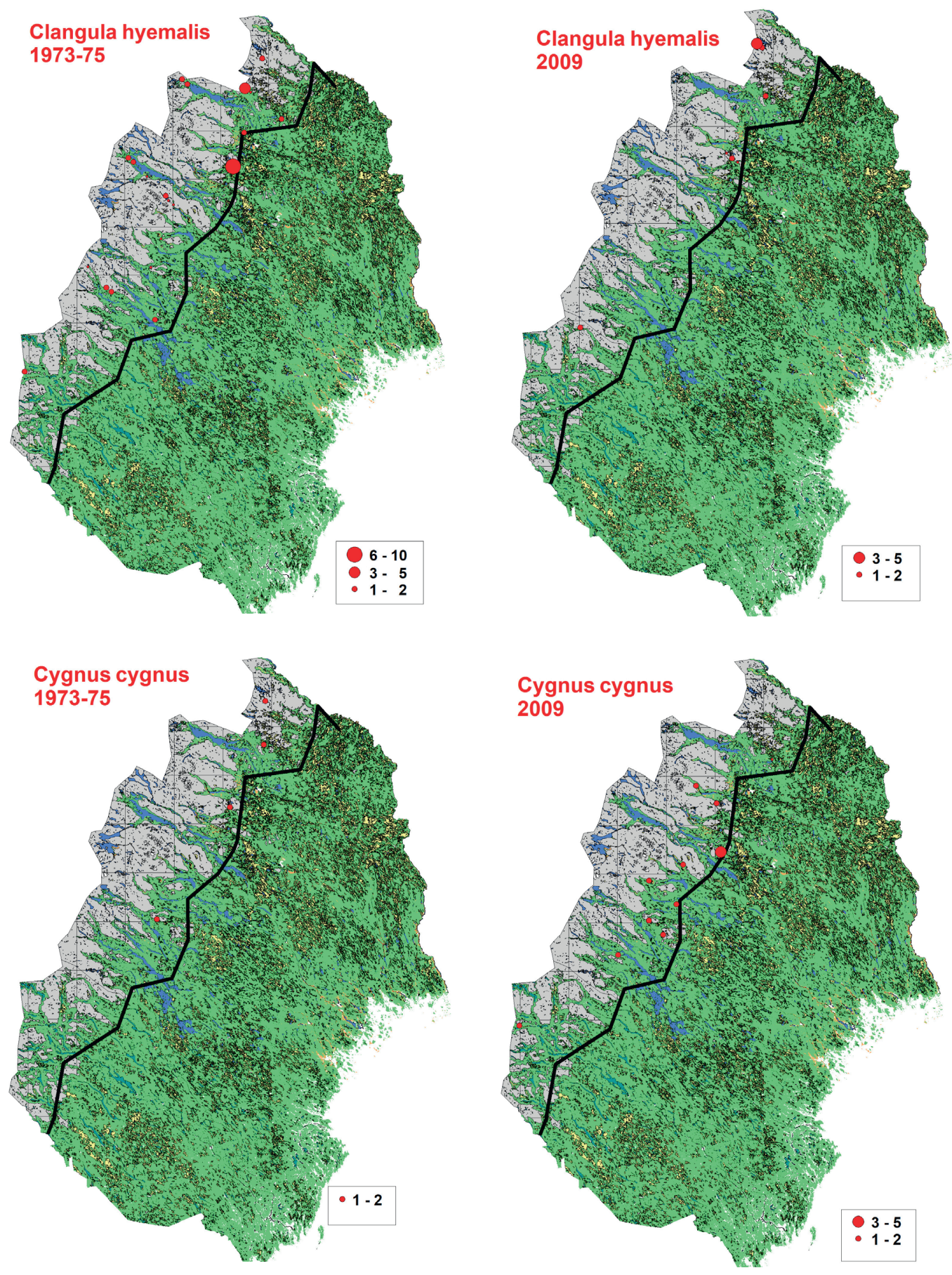

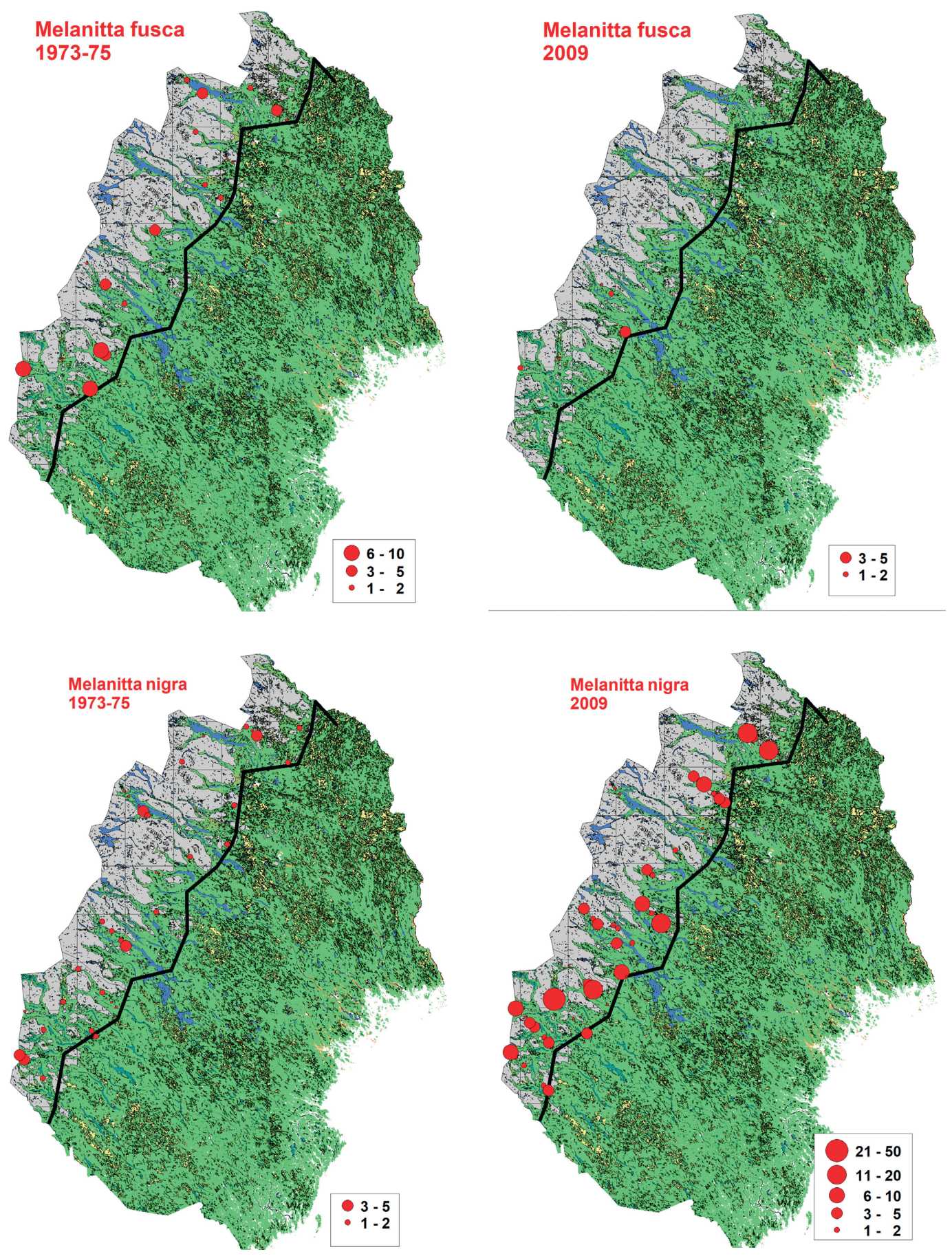

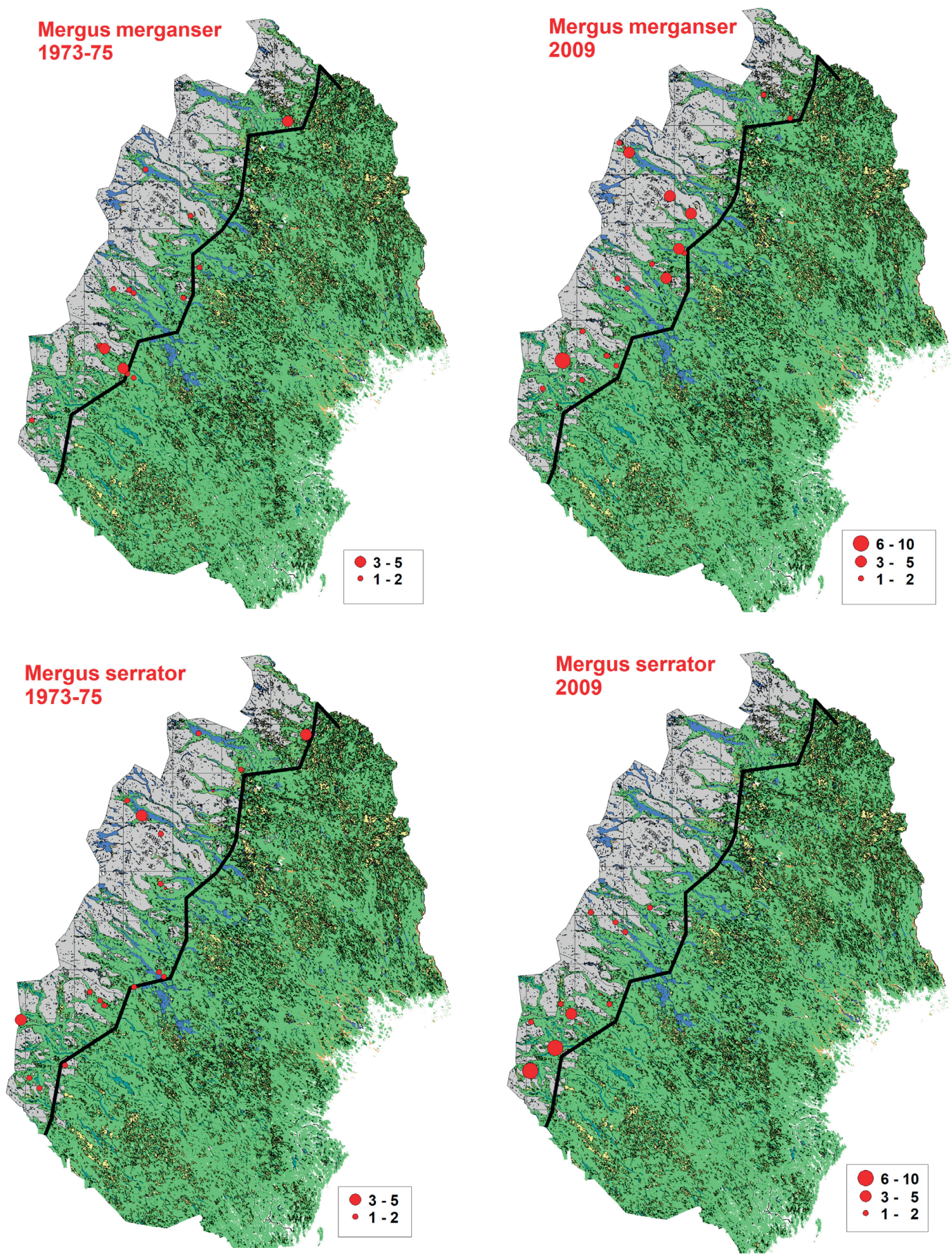
first periods. The marked increase was found in all areas except the two delta areas (Kvickjokk (4) and Rapadalen (6)) and Pårek-Kukkesvagge in Sarek (5).

Even if the Common Scoter has its main distribution in the mountain chain with the highest densities in the alpine and subalpine zones, it was also widely distributed in the boreal forest zone to the east of the mountain chain in the survey of the 1970s (Haapanen \& Nilsson 1979). Unfortunately there are no recent data available on the situation for the species in the forest zone. In 1972-1975, the northernmost area (sub-region D in Haapanen \& Nilsson 1979) of the forest zone had the same number of Common Scoters as the southern subregion in the mountain chain.

There are no data available on the population development of the Common Scoter from other breeding areas or from the wintering areas. It may be noted, that there was a documented change in the distribution of the Common Scoter in Finland during the decades before the 1972-1975 survey. In the boreal zone of Finland the species was a common breeder during the early years of the former century (Merikallio 1958), whereas relatively few were breeding in these areas during the 1970s (see also Haapanen 1966).

\section{Goosander Mergus merganser}

The Goosander was about equally and widely distributed during both surveys, but the number of pairs in 2009 was a lot higher than in the former period. Also the counts from the special study areas indicate an increase between the two periods. Numbers counted during the 1970s were quite low. The increase was localized to some areas: Tärnasjön (1), Björkfjället-Tjålmejaure (3) and SjaunjaKaitum (7), whereas the other areas had low counts in both time periods. The Goosander belongs to the species which are covered by the waterfowl counts in the winter, but these counts do not give any clear indications of any increase in the population over the period covered here.

\section{Red-breasted Merganser Mergus serrator}

In 1973-1975, the Red-breasted Merganser occurred in all three sub-regions, whereas in 2009, the records were concentrated in the southern sub-region with no or few records in the middle and northern sub-regions. In the special study areas the number of pairs was lower in 2009 than in the 1970s, whereas no change was found in the transect counts. Numbers counted in the special study areas was generally too low for analysis, but in the Sjaunja-Kaitum area (7) high totals were found in two years in the 1970s, but the other years showed low counts. The reasons for this variation are not known.

\section{Whooper Swan Cygnus cygnus}

The Whooper Swan is mainly a species of the forest zone but the distribution also extends into the valleys of the mountain chain and there are important populations in some mire areas at the foothills of the mountains. The transect counts showed an increase from 4 to 16 pairs, whereas the total number of pairs in the special study areas only increased from 26-35 to 47 pairs. The difference in the rate of increase between the two datasets is related to the inclusion of the Sjaunja-Kaitum (7) area among the special study areas. When the Whooper Swan population in Sweden was at its lowest level (about 20 pairs) during the 1920 s, Sjaunja was the main refuge for the species (Nilsson et al. 1998). In the 1970s between 15 and 23 pairs (mean 20) were found here. In 2009 the number of pairs had increased to 34. For the Whooper Swan, there is also a survey available from 1997 (Nilsson et al. 1998). In the Sjaunja Kaitum (7) area there were about 27 pairs in 1997. In Muddus national park (9) 25 pairs were found in 1997 compared to 22 in 2009.

With the exception of the large mire complexes in Sjaunja-Kaitum (7) and Muddus (9), the transects and special study areas covered in the comparisions here are more or less marginal areas for the Whooper Swan, which has its main distribution within the boreal zone. In recent years there has been a marked increase in the population of Whooper Swans in Sweden. In 1997 a national survey of the Whooper Swan was undertaken and the population in the entire provinces of Västerbotten and Norrbotten amounted to 2775 pairs compared to 310 during the 1972-1975 survey (Haapanen \& Nilsson 1979, Nilsson et al. 1998). The increase in the mountain chain is a reflection of this general population increase of the species.

\section{Acknowledgements}

The study was supported by grants from the Carl Trygger Foundation for Scientifique Research (both in 1972, 1973 and 2009), whereas the surveys in 1973-1975 were supported by grants from the Nordic Collegium for Wildlife Research (NKV). 

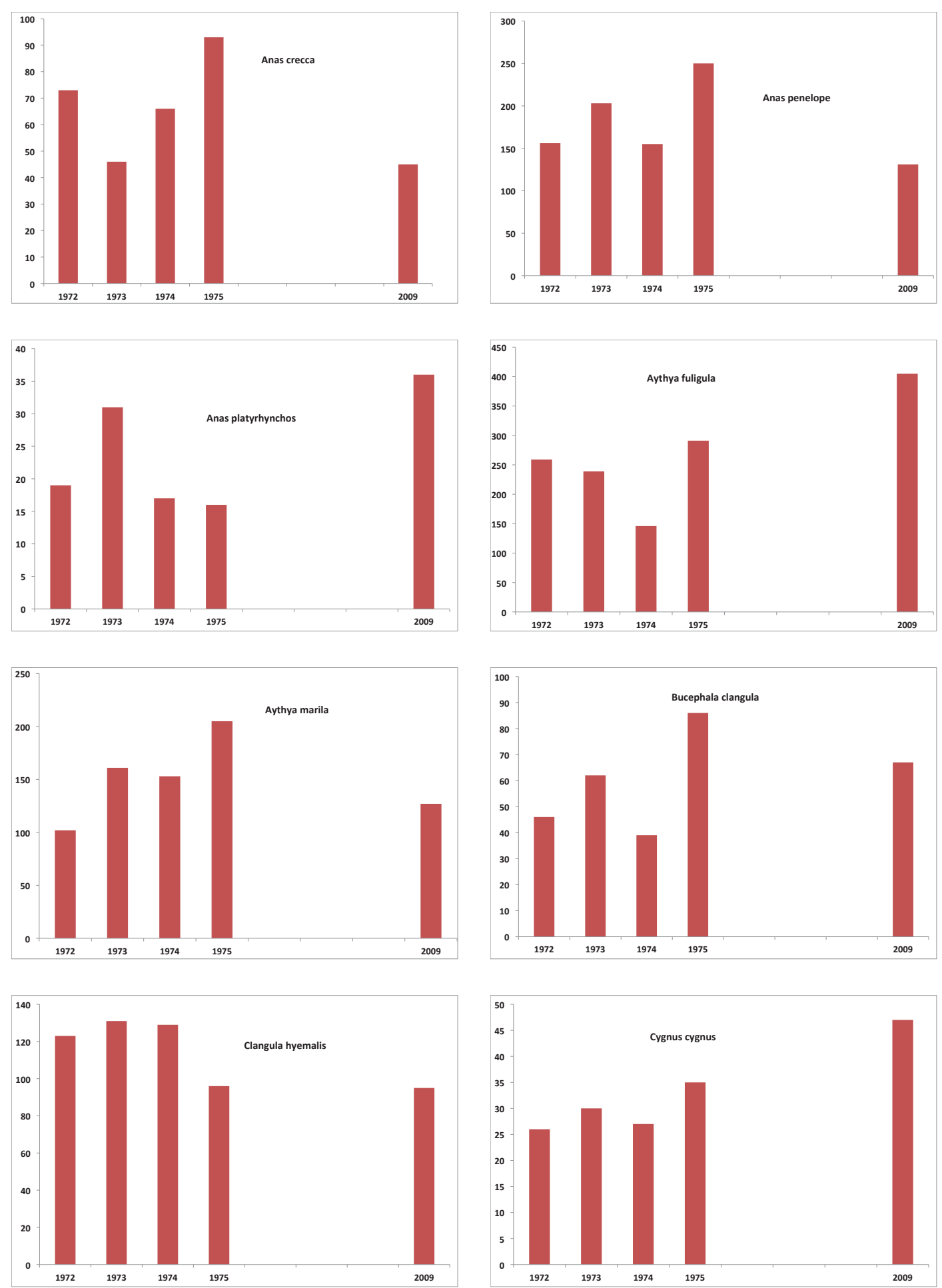

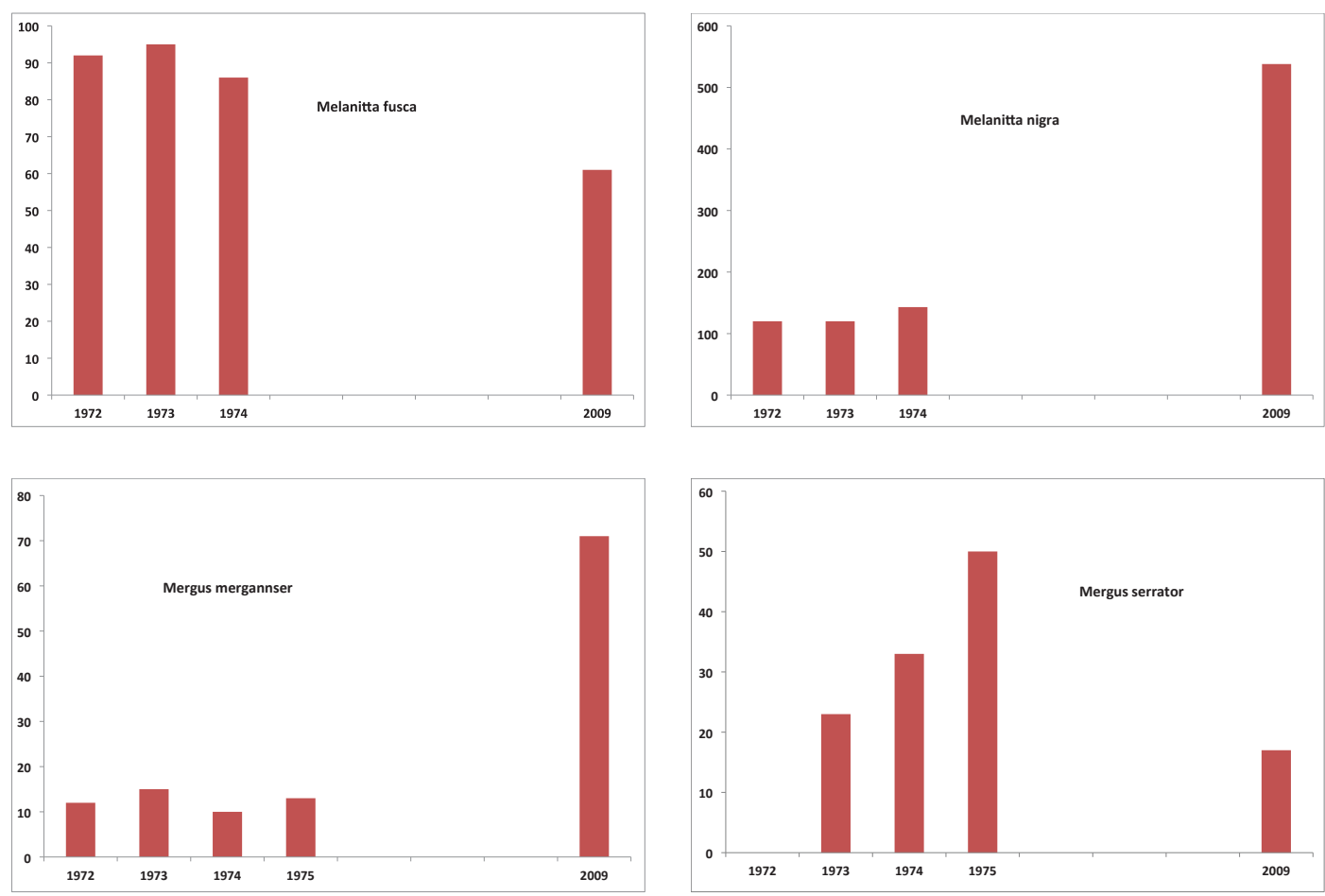

Figure 4. Total number of pairs counted of different species in the special study areas of the Swedish mountain chain (Figure 1) in 1972-1975 and 2009.

Antalet inräknade par av olika andfågelarter inom specialområden i den svenska fjällkedjan (Figur 1) $1972-1975$ och 2009.

Table 1. Total number of pairs counted of the different species in the parts of the transects counted both in 1973-1975 and in 2009 together with the number of squares in which the species was found.

Totalantalet par inräknade av de olika arterna i de delar av inventeringslinjerna som inventerades både 19731975 och 2009 tillsammans med antalet rutor där arten påträffats.

\begin{tabular}{lccrc}
\hline & \multicolumn{2}{c}{$1973-1975$} & \multicolumn{2}{c}{2009} \\
& Pairs & Squares & Pairs & Squares \\
\hline Mallard Anas platyrhynchos & 19 & 6 & 10 & 8 \\
Teal Anas crecca & 7 & 7 & 21 & 8 \\
Wigeon Anas penelope & 42 & 17 & 42 & 10 \\
Pintail Anas acuta & 1 & 1 & 0 & 0 \\
Scaup Aythya marila & 37 & 9 & 45 & 23 \\
Tufted Duck Aythya fuligula & 125 & 33 & 136 & 27 \\
Goldeneye Bucephala clangula & 72 & 25 & 93 & 25 \\
Long-tailed Duck Clangula hyemalis & 33 & 14 & 11 & 5 \\
Velvet Scoter Melanitta fusca & 56 & 14 & 19 & 3 \\
Common Scoter Melanitta nigra & 56 & 24 & 519 & 37 \\
Melanitta sp & 35 & & 29 & 10 \\
Red-breasted Merganser Mergus serrator & 29 & 17 & 41 & 18 \\
Goosander Mergus merganser & 26 & 14 & 16 & 10 \\
Whooper Swan Cygnus cygnus & 3 & 4 & & \\
\hline
\end{tabular}


Table 2. Number of pairs of the different species counted in special study areas or groups of such areas in 1972-1975 and 2009. For the geographical position of the areas see Figure 1.

Antalet inräknade par av de olika arterna i specialområdena eller grupper av sådana områden 1972-1975 och 2009. För områdenas geografiska läge se Figur 1.

\begin{tabular}{|c|c|c|c|c|c|}
\hline Mallard Anas platyrhynchos & 1972 & 1973 & 1974 & 1975 & 2009 \\
\hline Tärnasjön (1) & 4 & 8 & 3 & 2 & 1 \\
\hline S Ammarfjället (2) & 1 & 3 & 0 & 1 & 1 \\
\hline Björkfjället - Tjålmejaure (3) & 4 & 0 & 2 & 1 & 4 \\
\hline Kvickjokk delta (4) & 2 & 7 & 3 & 1 & 5 \\
\hline Pårek - Kukkesvagge (5) & 0 & 0 & 0 & 0 & 0 \\
\hline Rapadalen (6) & 0 & 6 & 8 & 1 & 6 \\
\hline Sjaunja - Kaitum (7) & 5 & 0 & 0 & 9 & 7 \\
\hline Tsåktso-Pirtimäsvuoma-Tavvavuoma (8) & 0 & 0 & 0 & 0 & 2 \\
\hline Teal Anas crecca & 1972 & 1973 & 1974 & 1975 & 2009 \\
\hline Tärnasjön (1) & 0 & 1 & 6 & 7 & 11 \\
\hline S Ammarfjället (2) & 8 & 0 & 0 & 0 & 3 \\
\hline Björkfjället - Tjålmejaure (3) & 6 & 1 & 3 & 3 & 4 \\
\hline Kvickjokk delta (4) & 0 & 4 & 10 & 1 & 0 \\
\hline Pårek - Kukkesvagge (5) & 0 & 1 & 0 & 0 & 1 \\
\hline Rapadalen (6) & 15 & 6 & 12 & 7 & 14 \\
\hline Sjaunja - Kaitum (7) & 23 & 15 & 15 & 38 & 2 \\
\hline Tsåktso-Pirtimäsvuoma-Tavvavuoma (8) & 21 & 10 & 17 & 31 & 9 \\
\hline Wigeon Anas penelope & 1972 & 1973 & 1974 & 1975 & 2009 \\
\hline Tärnasjön (1) & 5 & 6 & 2 & 8 & 14 \\
\hline S Ammarfjället (2) & 0 & 0 & 1 & 2 & 3 \\
\hline Björkfjället - Tjålmejaure (3) & 3 & 2 & 5 & 5 & 13 \\
\hline Kvickjokk delta (4) & 14 & 9 & 20 & 13 & 34 \\
\hline Pårek - Kukkesvagge (5) & 1 & 2 & 6 & 5 & 0 \\
\hline Rapadalen (6) & 64 & 107 & 34 & 76 & 42 \\
\hline Sjaunja - Kaitum (7) & 12 & 15 & 15 & 79 & 6 \\
\hline Tsåktso-Pirtimäsvuoma-Tavvavuoma (8) & 57 & 45 & 39 & 52 & 7 \\
\hline Pintail Anas acuta & 1972 & 1973 & 1974 & 1975 & 2009 \\
\hline Tärnasjön (1) & 1 & 0 & 0 & 0 & 0 \\
\hline S Ammarfjället (2) & 0 & 0 & 0 & 0 & 0 \\
\hline Björkfjället - Tjålmejaure (3) & 1 & 0 & 0 & 1 & 0 \\
\hline Kvickjokk delta (4) & 0 & 0 & 0 & 0 & 0 \\
\hline Pårek - Kukkesvagge (5) & 0 & 0 & 1 & 0 & 0 \\
\hline Rapadalen (6) & 0 & 1 & 1 & 1 & 8 \\
\hline Sjaunja - Kaitum (7) & 0 & 0 & 3 & 0 & 0 \\
\hline Tsåktso-Pirtimäsvuoma-Tavvavuoma (8) & 1 & 1 & 8 & 13 & 0 \\
\hline Shoveler Anas clypeata & 1972 & 1973 & 1974 & 1975 & 2009 \\
\hline Rapadalen (6) & 0 & 0 & 0 & 0 & 5 \\
\hline Scaup Aythya marila & 1972 & 1973 & 1974 & 1975 & 2009 \\
\hline Tärnasjön (1) & 22 & 11 & 14 & 18 & 6 \\
\hline S Ammarfjället (2) & 0 & 0 & 3 & 15 & 10 \\
\hline Björkfjället - Tjålmejaure (3) & 27 & 33 & 37 & 41 & 33 \\
\hline Kvickjokk delta (4) & 2 & 0 & 0 & 3 & 2 \\
\hline Pårek - Kukkesvagge (5) & 5 & 3 & 11 & 13 & 3 \\
\hline Rapadalen (6) & 2 & 19 & 16 & 23 & 32 \\
\hline Sjaunja - Kaitum (7) & 25 & 21 & 28 & 21 & 13 \\
\hline Tsåktso-Pirtimäsvuoma-Tavvavuoma (8) & 18 & 63 & 44 & 64 & 16 \\
\hline
\end{tabular}


Table 2 continued

\begin{tabular}{|c|c|c|c|c|c|}
\hline Tufted Duck Aythya fuligula & 1972 & 1973 & 1974 & 1975 & 2009 \\
\hline Tärnasjön (1) & 3 & 5 & 7 & 15 & 41 \\
\hline S Ammarfjället (2) & 6 & 2 & 2 & 2 & 9 \\
\hline Björkfjället - Tjålmejaure (3) & 1 & 1 & 5 & 5 & 35 \\
\hline Kvickjokk delta (4) & 4 & 1 & 6 & 0 & 20 \\
\hline Pårek - Kukkesvagge (5) & 11 & 3 & 3 & 2 & 15 \\
\hline Rapadalen (6) & 12 & 3 & 9 & 1 & 104 \\
\hline Sjaunja - Kaitum (7) & 69 & 62 & 43 & 161 & 59 \\
\hline Tsåktso-Pirtimäsvuoma-Tavvavuoma (8) & 144 & 131 & 60 & 101 & 61 \\
\hline Goldeneye Bucephala clangula & 1972 & 1973 & 1974 & 1975 & 2009 \\
\hline Tärnasjön (1) & 0 & 0 & 0 & 7 & 0 \\
\hline S Ammarfjället (2) & 2 & 1 & 0 & 4 & 2 \\
\hline Björkfjället - Tjålmejaure (3) & 0 & 11 & 0 & 14 & 4 \\
\hline Kvickjokk delta (4) & 7 & 14 & 8 & 6 & 5 \\
\hline Pårek - Kukkesvagge (5) & 2 & 0 & 1 & 3 & 0 \\
\hline Rapadalen (6) & 1 & 6 & 4 & 6 & 10 \\
\hline Sjaunja - Kaitum (7) & 11 & 17 & 15 & 39 & 27 \\
\hline Tsåktso-Pirtimäsvuoma-Tavvavuoma (8) & 6 & 1 & 1 & 0 & 6 \\
\hline Long-tailed Duck Clangula hyemalis & 1972 & 1973 & 1974 & 1975 & 2009 \\
\hline Tärnasjön (1) & 1 & 2 & 2 & 3 & 0 \\
\hline S Ammarfjället (2) & 0 & 2 & 8 & 2 & 3 \\
\hline Björkfjället - Tjålmejaure (3) & 6 & 0 & 15 & 4 & 10 \\
\hline Kvickjokk delta (4) & 0 & 0 & 0 & 0 & 0 \\
\hline Pårek - Kukkesvagge (5) & 3 & 11 & 11 & 5 & 0 \\
\hline Rapadalen (6) & 2 & 5 & 0 & 0 & 1 \\
\hline Sjaunja - Kaitum (7) & 2 & 8 & 9 & 20 & 4 \\
\hline Tsåktso-Pirtimäsvuoma-Tavvavuoma (8) & 92 & 95 & 83 & 58 & 51 \\
\hline Velvet Scoter Melanitta fusca & 1972 & 1973 & 1974 & 1975 & 2009 \\
\hline Tärnasjön (1) & 7 & 25 & 20 & 29 & 12 \\
\hline S Ammarfjället (2) & 1 & 2 & 2 & 18 & 2 \\
\hline Björkfjället - Tjålmejaure (3) & 18 & 15 & 15 & 32 & 31 \\
\hline Kvickjokk delta (4) & 3 & 1 & 1 & 1 & 0 \\
\hline Pårek - Kukkesvagge (5) & 15 & 1 & 2 & 5 & 0 \\
\hline Rapadalen (6) & 0 & 0 & 0 & 0 & 7 \\
\hline Sjaunja - Kaitum (7) & 12 & 18 & 18 & 52 & 5 \\
\hline Tsåktso-Pirtimäsvuoma-Tavvavuoma (8) & 30 & 27 & 23 & 19 & 0 \\
\hline Common Scoter Melanitta nigra & 1972 & 1973 & 1974 & 1975 & 2009 \\
\hline Tärnasjön (1) & 30 & 20 & 18 & 29 & 91 \\
\hline S Ammarfjället (2) & 8 & 0 & 12 & 11 & 23 \\
\hline Björkfjället - Tjålmejaure (3) & 16 & 12 & 36 & 32 & 161 \\
\hline Kvickjokk delta (4) & 3 & 6 & 3 & 2 & 1 \\
\hline Pårek - Kukkesvagge (5) & 3 & 1 & 9 & 5 & 10 \\
\hline Rapadalen (6) & 1 & 1 & 0 & 0 & 6 \\
\hline Sjaunja - Kaitum (7) & 25 & 34 & 48 & 75 & 112 \\
\hline Tsåktso-Pirtimäsvuoma-Tavvavuoma (8) & 36 & 28 & 17 & 26 & 88 \\
\hline
\end{tabular}


Table 2 continued

\begin{tabular}{|c|c|c|c|c|c|}
\hline Red-breasted merganser Mergus serrator & 1972 & 1973 & 1974 & 1975 & 2009 \\
\hline Tärnasjön (1) & 0 & 1 & 0 & 0 & 2 \\
\hline S Ammarfjället (2) & 0 & 0 & 2 & 3 & 0 \\
\hline Björkfjället - Tjålmejaure (3) & 0 & 1 & 7 & 7 & 2 \\
\hline Kvickjokk delta (4) & 0 & 1 & 2 & 1 & 0 \\
\hline Pårek - Kukkesvagge (5) & 1 & 1 & 3 & 0 & 0 \\
\hline Rapadalen (6) & 0 & 1 & 0 & 0 & 1 \\
\hline Sjaunja - Kaitum (7) & 3 & 6 & 16 & 38 & 3 \\
\hline Tsåktso-Pirtimäsvuoma-Tavvavuoma (8) & 1 & 3 & 7 & 1 & 1 \\
\hline Goosander Mergus merganser & 1972 & 1973 & 1974 & 1975 & 2009 \\
\hline Tärnasjön (1) & 0 & 2 & 0 & 1 & 11 \\
\hline S Ammarfjället (2) & 0 & 0 & 0 & 1 & 3 \\
\hline Björkfjället - Tjålmejaure (3) & 2 & 0 & 2 & 1 & 16 \\
\hline Kvickjokk delta (4) & 3 & 2 & 0 & 0 & 3 \\
\hline Pårek - Kukkesvagge (5) & 1 & 1 & 4 & 0 & 1 \\
\hline Rapadalen (6) & 2 & 1 & 0 & 0 & 4 \\
\hline Sjaunja - Kaitum (7) & 3 & 4 & 2 & 8 & 13 \\
\hline Tsåktso-Pirtimäsvuoma-Tavvavuoma (8) & 0 & 0 & 2 & 1 & 5 \\
\hline Smew Mergus albellus & 1972 & 1973 & 1974 & 1975 & 2009 \\
\hline Tärnasjön (1) & 0 & 1 & 0 & 0 & 0 \\
\hline Whooper Swan Cygnsu cygnus & 1972 & 1973 & 1974 & 1975 & 2009 \\
\hline Tärnasjön (1) & 0 & 0 & 0 & 0 & 1 \\
\hline S Ammarfjället (2) & 0 & 0 & 0 & 0 & 0 \\
\hline Björkfjället - Tjålmejaure (3) & 0 & 0 & 0 & 0 & 0 \\
\hline Kvickjokk delta (4) & 0 & 0 & 0 & 0 & 0 \\
\hline Pårek - Kukkesvagge (5) & 0 & 0 & 0 & 0 & 1 \\
\hline Rapadalen (6) & 2 & 2 & 0 & 2 & 1 \\
\hline Sjaunja - Kaitum (7) & 15 & 23 & 19 & 23 & 34 \\
\hline Tsåktso-Pirtimäsvuoma-Tavvavuoma (8) & 9 & 5 & 8 & 10 & 13 \\
\hline
\end{tabular}

\section{References}

Haapanen, A., Ulmanen, I. \& Valste, J. 1966. Observations on the bird fauna in Koitilaiskaira (Finnish Lapland). Ornis Fennica 43: 45-54.

Haapanen, A. \& Nilsson, L. 1979. Breeding waterfowl populations in northern Fennoscandia. Ornis Scandinavica 10: 145-219.

Martinson, R.K. \& Kaczynski, C.F. 1967. Factors influencing waterfowl counts on aerial surveys, 1961-66. US Dept. Interior Fish and Wildlife Service. Bureau of Sport Fisheries and Wildlife. Spec. Sci. Report Wildlife No 105.

Merikallio, E. 1958. Finnish birds, their distribution and numbers. Fauna Fennica 5: 1-181.

Nilsson, L. 1975. Midwinter distribution and numbers of Swedish Anatidae. Ornis Scandinavica 6: 83-107.

Nilsson, L. 2008. Changes of numbers and distribution of wintering waterfowl in Sweden during forty years, 19672006. Ornis Svecica 18: 135-226

Nilsson, L. Andersson, O., Gustafsson, R. \& Svensson, M. 1998. Increase and changes in distribution of breeding Whooper Swans Cygnus cygnus in northern Sweden from 1972-75 to 1997. Wildfowl 49: 6-17.

Ottvall, R., Edenius, L., Elmberg, J., Engström, H., Green, M., Holmqvist, N., Lindström, Å., Pärt, T. \& Tjernberg,
M. 2009. Population trends for Swedish breeding birds. Ornis Svecica 19: 117-192.

\section{Sammanfattning}

Den skandinaviska fjällkedjan liksom andra delar av norra Fennoskandien är rik på sjöar och myrar och utgör därmed ett viktigt häckningsområde för många våtmarksberoende arter. Området är också den västligaste delen av utbredningsområdet för många nordliga arter som är spridda från Skandinavien över hela norra Ryssland österut. Trots detta genomfördes den första översiktliga inventeringen av områdes andfågelfauna först under åren 19721975 (Haapanen \& Nilsson 1979). Under dessa fyra år täcktes Nordkalotten söderut ner till $68^{\circ} \mathrm{N} \mathrm{i}$ Norge, $65^{\circ}$ i Sverige och $64^{\circ}$ i Finland.

Efter den första inventeringen har området inte kunnat inventeras förrän 2009, då vi fick möjlighet att åter inventera den svenska delen i fjällkedjan. I denna uppsats jämför vi resultaten från inventeringen 2009 med den äldre inventeringen för att 
fastställa ev. förändringar i utbredning och populationsstorlek för andfåglarna i den norra delen av den svenska fjällkedjan.

\section{Undersökningsområde}

Den genomförda inventeringen 2009 täcker den del av den svenska fjällkedjan som ligger inom Lappland samt de angräsande områdena närmast öster om fjällkedjan. Områdets utsträckning framgår av kartan i Figur 1. Totalt omfattar det undersökta området $49500 \mathrm{~km}^{2}$. Vid Nordkalottinventeringen 1972-1975 delades området in i tre regioner A-C:

A har några högre fjäll, men regionen består till stor del av lågfjäll och platåer ca 400-600 m ö.h. Området har talrika småsjöar och stora delar är täckta av vidsträckta myrar. De flesta myrar särskilt i den norra delen och mot fjällen är palsmyrar, men i den södra delen återfinns den stora Sjaunjamyren som är av den s.k. aapa-typen.

B omfattar de höga fjällen bl.a. i nationalparksområdet kring Sarek. I regionen finns många större sjöar förutom småsjöarna, vilka ofta är ganska fattiga.

$C$ är den sydligaste regionen med lägre fjäll och många våtmarker på en höjd av $600-800$ m.öh. De flesta sjöar är oligotrofa, men det finns också en del rikare sjöar i regionen.

Olika habitattyper i undersökningsområdet illustreras i Figur 2 med foton från olika specialområden.

\section{Material och metodik}

För att kunna beräkna populationsstorlekarna för de olika arterna och för att studera deras habitatval organiserades Nordkalottinventeringen som en linjetaxering av $5 \times 5 \mathrm{~km}$ rutor efter diagonalerna i $100 \times 100 \mathrm{~km}$ rutorna i UTM-systemet. På detta sätt erhölls en täckningsgrad på 5\%. I fjällkedjan lades en extra inventeringslinje mellan de första varvid en täckningsgrad på $10 \%$ erhölls.

Förutom inventeringslinjerna etablerades också ett antal specialområden. Dessa var ursprungligen 34, men grupperades här i 10 enheter (Figur 1), varav område 1-8 utnyttjades i jämförelserna mellan perioderna. De 10 specialområdena beskrivs $\mathrm{i}$ Figur 2, som också visar typiska andfågelhabitat.

Vid inventeringarna spanades samtliga vattenområden och våtmarker inom rutorna och specialområdena av från luften. 1972-1975 utnyttjades vanliga högvingade flygplan (CESSNA 172 och 195), medan en mindre helikopter användes 2009. Antalet flygtimmar 2009 uppgick till 45. Vid in- venteringarna flög vi över samtliga områden med låg hastighet och på en låg (50-70 m) höjd. Om så behövdes flög vi runt observerade fåglar för att kunna fastställa arten säkert. Vid inventeringen 2009 dokumenterades flygvägen med GPS. Samtliga observationer talades in på diktafon och överfördes senare till en databas. Vid analyserna betraktades observationer av par samt hanar i grupper om 1-3 som indikation på antalet par i resp. ruta eller specialområde. För ytterligare beskrivningar hänvisas till Nilsson \& Haapanen (1979).

Totalt omfattade de tre delområdena 210 rutor i inventeringslinjerna. Vid inventeringarna 19731975 var 38 rutor i den högalpina delen helt istäckta, medan 9 rutor helt saknade vatten. Vid inventeringen 2009 inventerades 114 rutor, medan 65 högt belägna rutor antingen saknade vatten eller var isbelagda. Ytterligare 31 rutor kunde inte täckas på grund av flygrestriktioner (militärövningar etc.).

Inventeringarna 1972-1975 genomfördes under en utsträckt tidsperiod, varför det var möjligt att anpassa flygningarna efter isläget i fjällen. Inventeringarna 2009 genomfördes under en koncentrerad period (9-16 juni) och kom därför för tidigt för de högre belägna områdena. För jämförelserna på det regionala planet har detta inte så stor betydelse. Häckande änder på väg till de högre områdena återfanns då på lägre belägna sjöar och kom att täckas av inventeringarna $\mathrm{i}$ alla fall, men detta material är lite mindre lämpat för analys av utbredningen på detaljnivå.

\section{Resultat och diskussion}

Utbredningen i fjällkedjan för de vanligaste och mer spridda arterna vid inventeringen 2009 illustreras i Fig. 3, där de jämförs med inventeringen under 1972-1975. För jämförande utbredningskartor för hela Nordkalotten hänvisas till Haapanen \& Nilsson (1979).

En del skillnader i utbredning kunde konstateras mellan de båda inventeringstillfällena. Vid inventeringen 2009 var exempelvis bläsanden mer spridd i de sydligare delarna jämfört med de nordligare delarna av undersökningsområdet. Bland dykänderna kunde konstateras att berganden, sjöorren och svärtan hade ganska likartad utbredning mellan de båda inventeringstillfällena, men stora skillnader i antal noterades mellan svärta och sjöorre (se nedan!). Däremot konstaterades en jämn utbredning i fjällkedjan för vigg, vilken var dåligt spridd i den mellersta delen (region B) vid den tidigare inventeringen. För alfågeln är bilden från 2009 inte helt representativ på detaljnivå eftersom många högre 
belägna sjöar där alfågeln förekom 1972-1975 var frusna vid besöket 2009.

Sångsvanens allmänna spridning framgår också av de här presenterade inventeringarna. Arten förekommer i huvudsak i skogslandet, men utbredningen sträcker sig in i dalarna i fjällkedjan. Arten var betydligt mer spridd 2009 än vid den första inventeringen.

Vid inventeringen av specialområdena under 1972-1975 konstaterades betydande fluktuationer mellan åren för ett antal arter, medan andra arter visade en mer stabil nivå under fyraårsperioden (Figur 4). För vissa arter visade inventeringarna inom de olika specialområdena ibland olika mönster (Tabell 2). I jämförelserna mellan de båda tidsperioderna har vi använt oss både av data från specialområdena (Figur 4, Tabell 2) och linjetaxeringarna (Tabell 1).

För de tre vanligaste simänderna gräsand, kricka och bläsand visar de sammantagna resultaten från inventeringarna inga klara skillnader mellan de båda inventeringarna. Däremot kunde betydande skillnader konstateras mellan olika delområden för bläsanden. Vid inventeringen 2009 var bläsanden betydligt vanligare i Kvickjokk deltat jämfört med 1972-1975, medan det omvända förhållandet kunde konstateras för Rapadalen.

Berganden visade totalt samma beståndsnivå för båda perioderna, men lokalt tyder resultaten på en nedgång i de nordligaste områdena. För viggen konstaterades en ökad population i fjällkedjan mellan de båda inventeringarna, vilken ev. kan hänföras till en koncentration av viggar till vissa områden, där de väntade på att högre sjöar skulle bli isfria. Knipan förekommer huvudsakligen i skogslandet, men förekommer också i fjälldalarna, där den visade ungefär samma nivå vid de båda inventeringstillfällena.
När det gäller alfågeln har svårigheterna med isläget $\mathrm{i}$ högre lägen under 2009 redan nämnts. Inventeringarna 2009 visade i stort sett samma nivå som under 1972-1975, men i artens huvudområde på tundraområdena vid Tsåktso och Tavvavuoma (område 8) var antalet alfågelpar 2009 lägre än för tre av de fyra undersökningsåren 1972-1975.

Sjöorren visade ett avvikande mönster från övriga studerade arter. Arten var väl spridd över hela fjällkedjan och antalet par beräknades vara ungefär fem gånger högre än vid inventeringen 1972-1975. Ökningen var genomgående för alla specialområden med undantag för de båda stora deltaområdena vid Kvickjokk och Rapadalen samt Pårek-Kukkesvagge i Sarek. Däremot konstaterades en betydande nedgång för svärtan i hela det undersökta området.

Bland skrakarna konstaterades avsevärt högre antal storskrakar i vissa områden 2009 jämfört med den tidigare inventeringen. Däremot noterades inga mer betydande skillnader mellan de båda perioderna för småskraken.

Sångsvanen visade samman ökning mellan perioderna som noterats för landet som helhet och som konstaterades vid en inventering av hela Norrbotten och Västerbotten 1997 (Nilsson et al 1998). Ökningen i specialområdena var inte lika markant som för linjerna, vilket beror på att Sjaunja och Muddus ingår, dvs. de områden som fortfarande hyste sångsvanar när beståndet var på sin lägsta nivå.

Sammanfattningsvis kan man konstatera att inventeringarna inte visade några större förändringar i utbredning och antal i den lappländska fjällkedjan för de flesta arter mellan de båda inventeringarna. Undantagen är främst svärta, sjöorre och sångsvan samt i viss mån storskrake, vilka diskuterats ovan. 